military might". Yet he was convinced that it was only because of the war that democracy had performed so well. Remove the prod of war and the US government would revert to past form, as shown by the Truman administration's "exceedinglyloose" handling of arms control in late 1945.

Bush continued to have a profound distrust of 'politics as usual' and aspired to achieving a nonpartisan expertise that could transcend politics and produce the right answer through realistic observation of the facts and analysis untainted by wishful thinking and political preconceptions. This aspiration was closely approximated in his experience with the OSRD. There, shielded from public view by military secrecy, and with unlimited access to Roosevelt, he could acquire the resources and authority needed to fulfil his vision of an independent civilian research-and-development organization that would serve as an equal partner with the military and the industrial leadership of the country, but which would be free to initiate developments without military blessing.

According to Zachary, Bush first conceived of this wartime organization in January 1940 — a remarkably bold vision. "Few civilians short of the president had ever imagined so grand a role in military affairs," says Zachary.

According to Zachary, "Bush himself later confessed that the creation of NDRC [National Defense Research Committee] was 'an end run, a grab by which a small company of scientists and engineers, acting outside established channels, got hold of the authority and money for the program of developing new weapons'. Such a power grab was necessary to launch a 'broad program... on an adequate scale', Bush insisted, but he conceded that it stoked resentment against him." Bush attempted similar tactics in getting Roosevelt to commission "Science - The Endless Frontier", but the strategy did not work out in the more open, participatory environment in which it was released after the end of the war.

Nevertheless, in Bush's mind there remained an inherent tension between the increasingly complicated and technical problems facing government, even in peacetime, and the country's democratic traditions. Bush's solution was a body of civilian technocrats, nonpartisan experts of the highest calibre, free of operational responsibilities for departments or agencies, with delegations of authority to make decisions in the name of the president. In Bush's view their effectiveness would have to depend as much on their detachment from politics as on their specialized knowledge.

This is in a sense the uneasy compromise at which the United States has arrived in practice today with the enormous growth of the staff of the Executive Office and a matching growth of congressional staff and support agencies. But, as Zachary remarks, "the specialization of expertise [has] advanced knowledge but also expanded the possibilities for legitimate disputes about its import" with ample room for the intrusion of politics, especially in the overlapping domains between areas of expertise. We are still struggling for a solution today. This book does not provide one, but it does provide a wealth of new and valuable raw material for the continuation of the debate on expertise and democracy.

Harvey Brooks is emeritus professor at the John F.

Kennedy School of Government, Harvard

University, 79 JFK Street, Cambridge,

Massachusetts 02138, USA.

\section{A bluffer's guide}

\section{Loose Ends}

by Sydney Brenner

Current Biology: 1997. Pp. 128. £12.50, \$20

\section{Walter Gratzer}

In 1847, the aged Dr Routh, president of Magdalen and one of the foremost scholars of his day, was asked what precept he could offer to guide and sustain a young man embarking on a life of learning. After long thought, his face brightened and he spoke thus: "I think, sir, since you care for the advice of an old man sir, you will find it a very good practice always to verify your references, sir." A pragmatic suggestion for our time might be "read Molecular Biology of the Cell, but don't drop it on your foot". This is very much the level of inspiration afforded by most scientific memoirs, often sponsored by charitable foundations, that have appeared in such numbers in recent years.

A collection of Sydney Brenner's writings arouses altogether higher expectations and I am happy to report that indeed it will disappoint no one, for here we have the authentic voice of the master himself. These pieces have appeared in the back of the monthly issues of Current Biology, which tend therefore to vanish from our library the day they arrive. The appearance of a new number is generally heralded for me by a call from a friend in a lab up the road, asking me whether I have yet read Brenner this month and regaling me with a few of the more outrageous squibs.

Loose Ends are reflections on biology and the scientific life. Uncle Syd's epistles to his nephew Willie treading the path of academic virtue from graduate student to institute director are laced with pungent anecdotes from an eventful life. Uncle Syd expatiates on the value of intellectual innocence and the treacherous nature of experimental phenomena; he informs Willy that the most abject of research students has the advantage of his professor, who has little time for such trivia as the work of his laboratory. "I have to warn you," he concludes, "that, sadly, this may be the only time in your career when you can enjoy research as an individual scientist."

As Willie comes to man's estate, Uncle Syd proffers solutions to the problems that now face him - how, for instance, to avoid committees and conferences: the only acceptable excuse, he asserts, is to plead a prior meeting. To add conviction, Uncle Syd once invented a highly exclusive and mysterious society, which spawned numerous subcommittees to keep its members perpetually occupied. But at a pinch, he suggests, an inscrutable reply to an unwanted invitation, on the lines of "I regret that I am unable to accept your invitation as I find I cannot attend your meeting", will often serve, and has even been known to elicit a courteous acknowledgement. This is undoubtedly better than the telegraphic formula that Proust was said to have employed when he was being lionized by Parisian society: "Regret unable to come. Lie follows."

Willies the world over may also profit from Uncle Syd's tips on how to manipulate the old enemy, the bureaucrat. You can avert unpleasing decisions in committee by waiting until the administrators have formulated replies to your arguments and then confess that you were wrong after all and return to the original point. "You can do this," the wily Uncle Syd explains, "because the hallmark of a scientist is to be able to change one's views depending on the evidence; no administrator can do this." Here he is undoubtedly right. The legendary academic casuist Maurice Bowra gave it as principle never to allow scientists on committees: they were unreliable, he found, because their opinions could be changed by arguments. (It was also Bowra who announced, when outvoted by five to one, that the committee had evidently reached an impasse.)

Uncle Syd has also worked out how to use the telephone as a weapon, merely by reversing the postures of the caller and the respondent. This is an excellent device: when you have got past three secretaries and the Olympian grandee at the head of the organization finally comes on the line, you greet him with: "Why, hello, Sir Marmaduke, and what can I do for you today?"

In dilating on the seven deadly sins and their consequences, Uncle Syd again points a moral or two with some tantalizing anecdotes. Who was that editor of "an important biological journal" who submitted his work in an unworthy $\mathrm{PhD}$ thesis, examined and frivolously approved by Uncle Syd? The topic gives a clue, but a tormenting doubt hangs in the air. I believe, incidentally, that the seventh sin is not sloth, as here, but rather accidie, which lies somewhere between boredom and indifference. To me this is encapsulated by the perhaps rather sensible principle that if a research project is not worth doing at all it is not worth doing properly.

"Molecular Biology by Numbers" finds Brenner in top form with reflections on the science that he and a few friends mostly created. The number 1 stands for the principle of one gene, one enzyme, 2 the diploid chro- 
mosome and the double helix, 3 the codon, 4 the canonical nucleotides and 5 the pentagonal faces in an icosahedral virus. Brenner's luminous insights repeatedly bring you up short as you read. There is also here a certain nostalgia for a glorious past, when the problems of molecular biology yielded to cogitation and to discussion in the coffee room, and not merely to a brutal experimental assault.

In those days theory was king, and Niels Bohr's principle that one should never believe an experiment that was not confirmed by theory held sway. Occam's razor was complemented by Brenner's noble conceit of Occam's broom, which was used to sweep out of sight the more inconvenient facts. Today's technology allows important facets of nature to be brought to light at such a rate that, says Brenner, "pausing to think about the results, or asking how cells really work, is likely to be seen as a source of irritating delay to the managerial classes, and could even endanger the career of the questioner".

He deplores also the advent of researchby-kit, for we seem indeed to be heading for a future in which not only the sequencing of DNA and the production of antibodies, but also the identification of new genes and their products and in due course the very formulation of the questions themselves, will be farmed out to commercial organizations for money. And then perhaps the bureaucrats will suddenly find Utopia within their grasp, because the uncouth and refractory scientists will no longer be needed.

Brenner is dismayed by the relentless advance of bureaucracy in general. We have entered an age of strategic mission statements and management training courses. (The UK Medical Research Council actually offers courses in how to appraise and discipline technicians, though of course they are not called that now.) Security is another of his bugbears, although he does not mention safety, which is now the prime growth area in many organizations. To my mind, much the most dangerous place in most laboratories is the only one the safety officer habitually spares - the library, with its ever-present hazard that a bound volume of the J. Biol. Chem. will fall from a high shelf and make an end of you.

If, then, you are not the person who has razored out the last page of Current Biology and you want a guide to how to comport yourself in your scientific career and to survive and even thrive, then I urge you, for your pleasure and profit, to buy Uncle Syd's book. You may possibly (especially if you are one of the campfollowers of the profession) want to gratify him with the abusive letters and obscene telephone calls of which he has so far been disappointed. As the old bruiser Kingsley Amis once observed: "If you can't annoy somebody with what you write I think there is little point in writing."

Walter Gratzer is at the Randall Institute, King's

College London, London WC2B 5RL, UK.

\section{Life's dead letter}

\section{Lifelines: Biology, Freedom,} Determination

by Steven Rose

Allen Lane: 1997. Pp. 335. £20. To be

published in the United States by Oxford

University Press in January at \$30

\section{Benno Müller-Hill}

Genetics has been one of the most successful sciences of the twentieth century. Yet its history is not a simple success story. In the Soviet Union, genetics was almost destroyed. In Germany, it served as an argument for mass murder. In the United States, it was used to legitimize mass sterilization, laws against racial mixing and a restrictive immigration policy.

And today, a sizeable minority of the public looks at developments in genetics with disrespect.

Steven Rose is a biologist who has claimed in many books that something is deeply wrong with biology itself. In his latest offering, he suspects that the culprits are reductionism and biological determinism. He writes: "The challenge of the opponents of biological determinism is that, while we may have been effective in our critique of its reductionist claims, we have failed to offer a coherent alternative framework within which to interpret living processes... Lifelines originated as an attempt to meet the challenge."

Rose begins by presenting a brief history of biology and genetics. In a discussion of T. H. Morgan's work on mutant fruitflies, he writes that "they had red rather than white eyes". It was in fact the other way around! $\mathrm{He}$ then points out that "the proportion of unusual characters in the fly population could be greatly increased by stressing it in some way - for instance by exposing the flies to not-quite toxic concentrations of particular chemicals, or to radiation such as X-rays". It was H. J. Muller, not Morgan, who discovered the mutagenic action of X-rays. The reader will be confused by Rose's account of history.

One of Rose's central points is that genetics, which deals with single genes and gene products, is unable to illuminate the processes of development and evolution: "The great expansion of genetic knowledge in recent decades has yet to be matched by a comparable increase in the understanding of development."

He neglects to mention the work of Ed Lewis or Christiane Nüsslein-Volhard and their colleagues. In fruitflies, the first stages of development are now well understood, and in fish we may know them soon.

It is true that mouse and human development are still mysteries. But these mysteries are challenges to geneticists. Rose sees it dif- ferently: "Reductionist ideology has a number of serious consequences. It hinders us biologists from thinking adequately about the phenomena we wish to understand." I think he is wrong, and I hope he is unsuccessful in selling his idea to young biologists who might read this book.

Rose then sets out to attack the 'ultraDarwinists' Daniel Dennett and Richard Dawkins. Again, I think Rose's point is badly taken. "To isolate from this evolving web a single factor, be it a gene or organism, as the unique determinant of change is as problematic as isolating a single enzyme from the metabolic web that constitutes the cell. Any such attempt at isolation is a reductionism that mistakes method for theory." I and many others have put some effort into isolating such genes and I remain convinced that the results of our studies have better illuminated our understanding of the living cell.

After warning his readers against the dangerously seductive character of metaphors, Rose presents us with those of his own choice.

Here is a selection: "We must speak of the dialectic of specificity and plasticity during development, the dialectic through which the living organism constructs itself"; "...to offer a perspective on biology which transcends genetic reductionism, by placing the organism, rather than the gene at the centre of life - this perspective I call homeodynamic"; "Our lives form a developmental trajectory, or lifeline, stabilised by the operation of homeodynamic principles. This trajectory is not determined by our genes, nor partitioned into neatly dichotomous categories called nature and nurture. Rather it is an autopoietic process". These quotations give the flavour of what is to replace reductionism if we follow Rose.

So we come to what seems to me the central issue. Rose argues that "the argument against hunting for neurogenetic explanations (for violence etc.) is not that it is immoral or unethical to do so. It is simply that, despite the seductive power of reductionism it is the wrong level of the disciplinary pyramid". To my mind, violent crime is not part of science. If it is made part of genetics, it converts genetics into an ideology or religion, as has been demonstrated in Nazi Germany.

Finally, Rose sets about "making Biology whole again" by delivering, as a new Moses of biology, "biology's Decalogue". As far as I could tell, it bears no resemblance whatsoever to the old Decalogue. To quote its last sentence: "And it is therefore our biology that makes us free."

If I had to choose, I'd prefer the Mosaic version.

Benno Müller-Hill is at the Institute of

Genetics, University of Cologne, Cologne 50931,

Germany. 